\title{
An Overview of Some Important Issues Related to Wind Energy Conversion System (WECS)
}

\author{
Rajveer Mittal, K.S.Sandhu and D.K.Jain
}

\begin{abstract}
Wind power capacity has experienced tremendous growth in the past decade. There are many loads (such as remote villages, islands, ships etc) that are away from the main grid. They require stand-alone generator system (which can provide constant nominal voltage and frequency) to provide for their local electrification. This requirement has lead to widespread research on development of new technologies for stand-alone generators. Initially an overview of different existing generator technologies for grid connected operation is given. This paper presents the recent developments in wind energy conversion systems, their classifications, choice of generators and their social and environmental benefits, a review of the interconnection issues of distributed resources including wind power with electric power systems, hybrid power system and reports the developments of interconnection standards in Canada and IEEE.
\end{abstract}

Index Terms-wind energy conversion system, interconnection, power quality, renewable energy, wind turbine, Hybrid Power Systems.

\section{INTRODUCTION}

The major components of a typical wind energy conversion system include a wind turbine, generator, interconnection apparatus and control systems. Wind turbines can be classified into the vertical axis type and the horizontal axis type. Most modern wind turbines use a horizontal axis configuration with two or three blades, operating either down-wind or up-wind. A wind turbine can be designed for a constant speed or variable speed operation. Variable speed wind turbines can produce $8 \%$ to $15 \%$ more energy output as compared to their constant speed counterparts, however, they necessitate power electronic converters to provide a fixed frequency and fixed voltage power to their loads. Most turbine manufacturers have opted for reduction gears between the low speed turbine rotor and the high speed three-phase generators. Direct drive configuration, where a generator is coupled to the rotor of a wind turbine directly, offers high reliability, low maintenance, and possibly low cost for certain turbines. Several manufacturers have opted for the direct drive configuration in the recent turbine designs. At the present time and in the near future, generators for wind turbines will be synchronous generators, permanent magnet synchronous generators, and induction generators, including the squirrel cage type and wound rotor type.

Rajveer Mittal is with the Department of Electrical and Electronics Engineering, Maharaja Agrasen Institute of Technology, Rohini,Delhi , India (e-mail : rajveermittal@yahoo.com, : rajveermittal@hotmail.com )

K.S Sandhu is with the Department of Electrical Engineering, N.I.T, Kurukshetra, Haryana, India. (e-mail 1:kjssandhu@yahoo.com.).

D. K. Jain is with the Guru Prem Sukh Memorial College of engineering under GGSIP University, Delhi, India. (e-mail: jaindk66@gmail.com).
For small to medium power wind turbines, permanent magnet generators and squirrel cage induction generators are often used because of their reliability and cost advantages. Induction generators, permanent magnet synchronous generators and wound field synchronous generators are currently used in various high power wind turbines. Interconnection apparatuses are devices to achieve power control, soft start and interconnection functions. Very often power electronic converters are used as such devices. Most modern turbine inverters are forced commutated PWM inverters to provide a fixed voltage and fixed frequency output with a high power quality. Both voltage source voltage controlled inverters and voltage source current controlled inverters have been applied in wind turbines. For certain high power wind turbines, effective power control can be achieved with double PWM (pulse width modulation) converters which provide a bi-directional power flow between the turbine generator and the utility grid.

Capacity factor-Since wind speed is not constant so annual energy production is never as much as the sum of the generator nameplate ratings multiplied by the total hours in a year. The ratio of actual productivity in a year to this theoretical maximum is called the capacity factor. Typical capacity factors are $20-40 \%$, with values at the upper end of the range in particularly favorable sites.[1,2] For example, a 1 megawatt turbine with a capacity factor of $35 \%$ will not produce 8,760 megawatt-hours in a year $(1 \times 24 \times 365)$, but only $0.35 \times 24 \times 365=3,066 \mathrm{MWh}$, averaging to $0.35 \mathrm{MW}$. Online data is available for some locations and the capacity factor can be calculated from the yearly output $[3,4]$

Unlike fueled generating plants, the capacity factor is limited by the inherent properties of wind. Capacity factors of other types of power plant are based mostly on fuel cost, with a small amount of downtime for maintenance. Nuclear plants have low incremental fuel cost, and so are run at full output and achieve a 90\% capacity factor.[5] Plants with higher fuel cost are throttled back to follow load. Gas turbine plants using natural gas as fuel may be very expensive to operate and may be run only to meet peak power demand. A gas turbine plant may have an annual capacity factor of $5-25 \%$ due to relatively high energy production cost. According to a 2007 Stanford University study published in the Journal of Applied Meteorology and Climatology, interconnecting ten or more wind farms allows 33 to $47 \%$ of the total energy produced to be used as reliable, base load electric power, as long as minimum criteria are met for wind speed and turbine height.[6,7] 


\section{ClASSIFICATION OF WIND ENERGY CONVERSION} SYSTEMS

There are number of ways to classifying the WECs. Following are the main types of classifications of WECs:

\section{A. According to size of Electrical Power Output. [19]}

(i) Small size (up to $2 \mathrm{~kW}$ ): These may be used for remote applications, or at places requiring relatively low power.

(ii) Medium Size $(2-100 \mathrm{~kW})$ : These turbines may be used to supply less than $100 \mathrm{~kW}$ rated capacity, to several residences or local use.

(iii)Large Size (100 kW and up): They are used to generate power for distribution in central power grids.

\section{B. According to type of electrical power output ;}

There are mainly following three classes of generators:[16]

\section{1) D.C. generators}

D.C. generators are relatively unusual in wind/microhydro turbine applications because they are expensive and require regular maintenance. Nowadays for most of d.c. applications, for example, it is more common to employ an a.c. generator to generate a.c., which is then converted to d.c. with simple solid-state rectifiers.

\section{2) Synchronous generators}

The major advantage of synchronous generator is that its reactive power characteristic can be controlled and therefore such machines can be used to supply reactive power to other items of power systems, which require the reactive power. It is normal for a stand-alone wind-diesel system to have a synchronous generator, usually connected to the diesel. Synchronous generators when fitted to a wind turbine must be controlled carefully to prevent the rotor speed accelerating through synchronous speed especially during turbulent winds. Moreover it requires flexible coupling in the drive train, or to mount the gearbox assembly on springs or dampers to absorb turbulence. Synchronous generators are more costly than induction generators, particularly in smaller size ranges. Synchronous generators are more prone to failures.

\section{3) Induction generators}

Induction generator offers many advantages over a conventional synchronous generator as a source of isolated power supply. Reduced unit cost, ruggedness, brush less (in squirrel cage construction), reduced size, absence of separate DC source and ease of maintenance, self-protection against severe overloads and short circuits, are the main advantages Further induction generators are loosely coupled devices, i.e. they are heavily damped and therefore have the ability to absorb slight change in rotor speed and drive train transient to some extent can therefore be absorbed. Whereas synchronous generators are closely coupled devices and when they are used in wind turbines which is subjected to turbulence and requires additional damping devices such as flexible couplings in the derive train or to mount gearbox assembly on springs and dampers. Reactive power consumption and poor voltage regulation under varying speed are the major drawback of the induction generators, but the development of static power converters has facilitated the control of induction generator, regarding output voltage and frequency.

\section{According to Rotational Speed of Aeroturbines:}

Several kinds of generator technologies have been developed and are in use today. In this section a short overview of these different generator topologies is presented. Each of them is discussed with its advantages and drawbacks.

\section{1) fixed speed system}

Fixed speed systems are the simplest and most widely used arrangement. They operate at constant (or nearly constant) speed [also called constant speed constant frequency (CSCF) mode of operation]. This implies that regardless of the prime mover speed, the angular speed of the rotor is fixed and determined by the frequency of supply grid and gear ratio This arrangement, in general, has simple and reliable construction of the electrical part while the mechanical parts are subject to higher stresses and additional safety factors need to be incorporated in the mechanical design. This arrangement can use induction generator (IG) and the wound rotor synchronous generator (SG) as the electric machine. But the squirrel cage induction generator has been the prevalent choice. The reasons for this popularity are mainly due to its simplicity, high efficiency and low maintenance requirements. To compensate for the reactive power consumption of the induction generator, a capacitor bank (normally stepwise controlled) is inserted in parallel with the generator in order to obtain about unity power factor. Further, to reduce the mechanical stress and to reduce the interaction between supply grid and turbine during connection and start-up of the turbine, a soft starter is used. The main advantage of this system is that it is a simple and reliable arrangement. However, capacitors need to be cutin or cutoff regularly to maintain power factor. This random switching gives rise to undesirable transients in the line currents and voltages. The fluctuations in prime mover speed are converted to torque pulsations, which cause mechanical stress. This causes breakdown of drive train and gear box. The power generated from this arrangement is sensitive to fluctuations in prime mover speed. To avoid this pitch control of rotor blades is required.

The Fixed Speed Induction Generators (FSIG) wind turbine is a simple squirrel cage induction generator, which can be directly coupled to the electricity supply network. The frequency of the network determines the rotational speed of the stator's magnetic field, while the generator's rotor speed changes as its electrical output changes. However, because of the well known steep torque- Slip characteristic of the induction machine, the operating range of the generator is very limited. The wind turbine is therefore effectively fixed speed. FSIGs do not have the capability of independent control of active and reactive power, which is their main disadvantage. Their great advantage is their simple and robust construction, which leads to lower capital cost. In contrast to other generator topologies, FSIGs offer no inherent means of torque oscillation damping which places greater burden and cost on their gearbox. The wind energy system and power quality aspects are discussed in detail in the literature

The Doubly Fed Induction Generators (DFIG) Wind 
Turbines is a wound rotor induction generator whose rotor is fed via slip rings by a frequency converter. The stator is directly coupled to the electrical power supply network. As a result of the use of the frequency converter, the network frequency is decoupled from the mechanical speed of the machine and variable speed operation is possible, permitting maximum absorption of wind power. Since power ratings are a function of slip, DFIGs operate over a range of speeds between about 0.75 and 1.25 pu of synchronous frequency, which requires converter power ratings of approximately $25 \%$. A great advantage of the DFIG wind turbine is that it has the capability to independently control active and reactive power. Moreover, the mechanical stresses on a DFIG wind turbine are reduced in comparison to a FSIG. Due to the decoupling between mechanical speed and electrical frequency that results from DFIG operation, the rotor can act as an energy storage system, absorbing torque pulsations caused by wind gusts. Other advantages of the DFIG include reduced flicker and acoustic noise in comparison to FSIGs. The main disadvantages of DFIG wind turbines in comparison to FSIGs are their increased capital cost and the need for periodic slip ring maintenance.

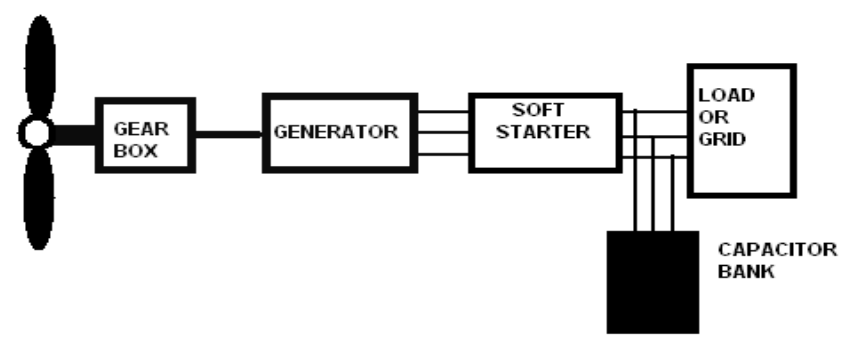

Fig.1. General arrangement of fixed-speed generation system

\section{2) Fully Variable Speed System}

With the increase in the size of turbine, the inherent problems of the constant speed systems become more and more pronounced, especially in areas with relatively weak grids. To overcome these problems, the trend in modern generator technology is toward variable-speed concepts. A variable-speed system keeps the generator torque constant and it is the generator speed which changes. Variations in the incoming power are absorbed by rotor speed changes. The variable-speed system therefore incorporates a generator control system that can operate with variable speed. In this arrangement the variable-voltage variable frequency (VVVF) power generated by the machine is converter to fixed-frequency fixed voltage power by the use of back to back power converters. The arrangement can have either induction generator or synchronous generator as the electric machine. The machine side converter supplies the lagging excitation to the machine while the line side converter maintains unity power factor at grid interface and also regulates the dc link voltage constant. The synchronous machine offers the least possible configuration for a variable-speed sys- tem. It can operate without gear box, with a good multi-pole design. This is an important objective since gear box is a component that has a tendency to fail. The advantages of this scheme are that mechanical oscillations in the drive train are absent as it is in fixed speed systems. The torque is under control if Direct Torque Control or Field Oriented Control techniques are used. This does not allow the generator to be overloaded. Gear box is not required with a multi-pole synchronous machine. However, converters have to manage entire generated power. Therefore they have to be rated equal to machine rating. Inverter output filters and EMI output filters are rated for 1 p.u ( with respect to output power) making filter design difficult and expensive. Converter efficiency plays an important factor in total system efficiency over the entire operating range. It cannot be operated above synchronous speed with full torque.

\section{a) Direct Drive Synchronous Generator Wind Turbine}

An alternative to the much-used induction machine generator is the use of a multipole synchronous generator, fed through a power electronic AC/DC/AC stage. The excitation of the synchronous generator can be given either by an electrical excitation system or by permanent magnets. The AC/DC/AC converter acts as a frequency converter and decouples the generator from the Grid. It consists of two back-to-back voltage source converters, usually with IGBT switches, which can independently control the active power transfer through the DC link and the reactive power output at each converter terminal .The speed range is generally similar to that of DFIGs. The multipole construction of the synchronous generator leads to a low mechanical rotational speed of the generator rotor and can permit direct coupling to the wind turbine. The possibility of reducing the number of stages in the gearbox or eliminating it completely is often quoted as an advantage of direct drive synchronous generator wind turbines. However set against this is the greater VA rating of the power electronic converter compared with DFIGs and the larger physical generator size. As a result of the increased mechanical stresses experienced by FSIG wind turbines at present there is a practical limit to the rating of commercial models of this technology. All present commercial models for multi-MW wind turbines in the range above $3 \mathrm{MW}$ are either DFIGs, or synchronous generators coupled to the network through back-to-back converters.

A comparison between the variable speed wind turbine and the constant speed wind turbine shows that variable speed reduce mechanical stresses: gusts of wind can be absorbed, dynamically compensate for torque and power pulsations caused by back pressure of the tower. This backpressure causes noticeable torque pulsations at a rate equal to the turbine rotor speed times the number of rotor blades. The used of a doubly fed induction generator in WECS with the rotor connected to the electric grid through an AC-AC converter offers the following advantages:

- Only the electric power injected by the rotor needs to be handled by the convert, implying a less cost AC-AC converter.

- Improved system efficiency and power factor control can be implemented at lower cost the converter has to provide only excitation energy.

Hence, taking advantage of power electronic advances in recent years, WECS equipped with doubly fed induction generator systems for variable speed wind turbine are one of the most efficient configurations for wind energy 
conversion

b) PM synchronous generator

The scheme of a grid-connected PMSG for direct-drive wind turbines is shown in Fig. 2. The advantages of PM machines over electrically excited machines can be summarized as follows according to literatures:

- Higher efficiency and energy yield.

- No additional power supply for the magnet field excitation,

- Improvement in the thermal characteristics of the PM machine due to the absence of the field losses,

- Higher reliability due to the absence of mechanical components such as slip rings,

- Lighter and therefore higher power to weight ratio.

However, PM machines have some disadvantages, which can be summarized as follows:

- high cost of PM material,

- difficulties to handle in manufacture,

- Demagnetization of PM at high temperature.

In recent years, the use of PMs is more attractive than before, because the performance of PMs is improving and the cost of PM is decreasing. The trends make PM machines with a full-scale power converter more attractive for directdrive wind turbines. Considering the performance of PMs is improving and the cost of PM is decreasing in recent years, in addition to that the cost of power electronics is decreasing, variable speed direct-drive PM machines with a full-scale power converter become more attractive for offshore wind powers. On the other hand, variable speed concepts with a full-scale power converter and a single- or multiple-stage gearbox drive train may be interesting solutions not only in respect to the annual energy yield per cost but also in respect to the total weight. For example, the market interest of PMSG system with a multiple-stage gearbox or a single-stage gearbox is increasing [38].

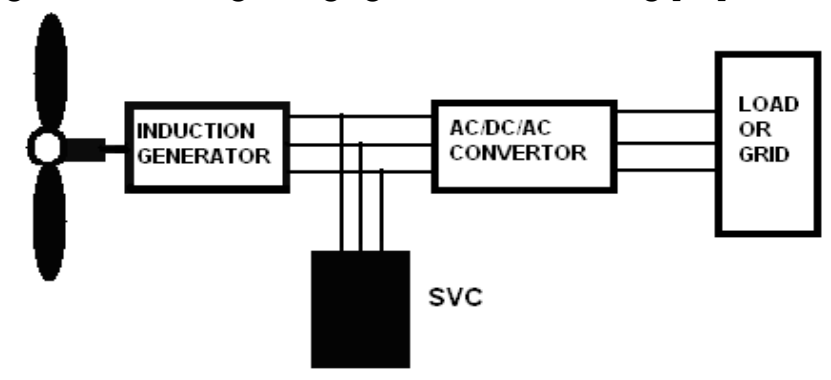

Fig. 2. General arrangement of the full variable-speed system.

\section{3) Limited Variable-speed systems}

Compared to the squirrel-cage induction generator, the main difference that the doubly- fed induction generator configuration provides is the access to the rotor windings, thereby giving the possibility of impressing the rotor voltage. With this arrangement, power can be extracted from or fed to the rotor circuit and the generator can be magnetized from either the stator circuit or the rotor circuit. Basically two methods of speed control can be applied to the induction generator, namely rotor resistance control and back to back converter control. The effective scheme for limited variable speed system is back to back converter used doubly-fed configuration. Fig. 4 shows this topology, the stator is directly connected to the grid, while the rotor is connected via slip rings to the converter. The gear ratio is set so that the nominal speed of the induction generator corresponds to the middle value of the rotor-speed range of the turbine. This is done to minimize the size of the inverter, which will vary with rotor-speed range. A step up transformer is required between the line side converter and utility, to match the voltage ratio between the stator and rotor in the machine. This [38] configuration with two converters offers many advantages. The main features of this configuration are listed below:

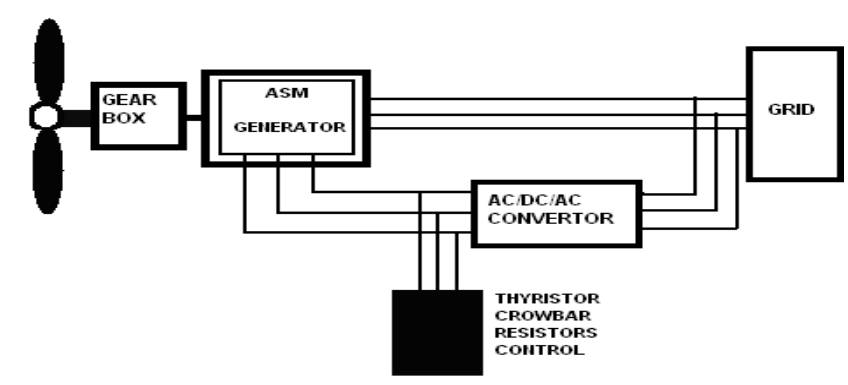

Fig. 3. General arrangement of limited variable-speed system with Doublyfed configuration.

1. Reduced converter cost, as they have to be rated for slip power only (typically about $0.25 \mathrm{pu}$ ).

2. Converter on the rotor side enables both positive and negative slip power control through control of rotor current in phase magnitude and frequency. This allows both sub synchronous and super-synchronous operation.

3. DC link capacitor acts as a source of reactive power, which in a way can control power factor on the stator side.

4. Line side converter has ability to work as active filter, apart from maintaining unity power factor operation and regulating dc bus voltage.

5. Reduced cost and weight of inverter filter and EMI filters (to about $0.25 \mathrm{pu}$ of total system power). Inverter harmonics represent a fraction of total system harmonics.

6. System efficiency is better, due to reduced losses in the converters.

Important developments in the technology of doubly-fed system occurred in last two decades. With the advances in power electronic devices and digital signal processors, it is now feasible to implement complex algorithms such as field oriented control etc easily. This had lead to new technologies or grid connected generators using doubly-fed configuration.

\section{According to the orientation of turbines:}

A wind turbine is a rotating machine which converts the kinetic energy in wind into mechanical energy. If the mechanical energy is used directly by machinery, such as a pump or grinding stones, the machine is usually called a windmill There are two great classes of wind turbines, horizontal and vertical axis machines:[17,18]

\section{1) Horizontal Axis wind turbines (HAWT)}

In horizontal axis wind turbines (HAWT), the axis of rotation is parallel to the direction of the wind. There may be many designs of the horizontal axis windmills. Depending upon the number of blades these may be 
classified as single-bladed, double-bladed, three-bladed, multi-bladed and bicycle-bladed. [12,17]Depending upon the orientation of the blades with respect to wind direction these may be classified as up-wind and down-wind type. As the wind changes direction, all horizontal axis in the wind machines have some means for keeping the rotor in to wind. Consequently, either the entire wind machine and its tower, or the top of the wind machine where the rotor is attached must change its position relative to the wind. On smaller wind machines, such as the farm windmill the tail vane keeps the rotor pointed in to wind regardless of changes in wind direction. Both tail vanes and fan tails use forces in the wind itself to orient the rotor upwind of the tower. They passively change the orientation of the wind turbine with respect to changes in the wind direction without the use of human or electrical power. Down wind rotors don't need tail vanes or fantails. Instead the blades are swept slightly down wind, giving the spinning rotor the shape of a shallow cone with its apex at the tower. This coning of the blades causes the rotor to inherently orient itself down wind.

\section{Advantages of Horizontal Axis wind turbines (HAWT)[11,12]}

- Variable blade pitch, which gives the turbine blades the optimum angle of attack. Allowing the angle of attack to be remotely adjusted gives greater control, so the turbine collects the maximum amount of wind energy for the time of day and season.

- The tall tower base allows access to stronger wind in sites with wind shear. In some wind shear sites, every ten meters up, the wind speed can increase by $20 \%$ and the power output by $34 \%$.

\section{Disadvantages of Horizontal Axis wind turbines (HAWT)[11,12]}

- HAWTs have difficulty operating in near ground turbulent winds.

- The tall towers and blades up to 90 meters long are difficult to transport. Transportation can now cost $20 \%$ of equipment costs.

- $\quad$ Tall HAWTs are difficult to install, needing very tall and expensive cranes and skilled operators.

- Massive tower construction is required to support the heavy blades, gearbox, and generator.

- Tall HAWTs may affect airport radar.

- Their height makes them obtrusively visible across large areas, disrupting the appearance of the landscape and sometimes creating local opposition.

- Downwind variants suffer from fatigue and structural failure caused by turbulence.

- HAWTs require an additional yaw control mechanism to turn the blades toward the wind.

\section{2) Vertical Axis wind turbines (VAWT)}

In vertical axis wind turbines (VAWT), the axis of rotation is perpendicular to the direction of wind. These machines are also called as cross-wind axis machines. Main designs of vertical axis machines are Savonious rotor and Darrieus rotor. The principal advantages of VAWT over conventional HAWT are that VAWT are omni directional, i.e. they accept the wind from any direction. This simplifies their design and eliminates the problem imposed by gyroscopic forces on the rotor of conventional machines as the turbines yaw into the wind. The vertical axis rotation also permits mounting the generator and gear at the ground level.[19] On the negative side VAWT requires guy wires attached to the top for the support, which may limit its application particularly for the offshore sites.

\section{Advantages of Vertical Axis wind turbines (VAWT)[11,12]}

- $\quad$ No massive tower structure is needed.

- As the rotor blades are vertical no yaw mechanism is needed.

- $\quad$ A VAWT can be located nearer the ground, making it easier to maintain the moving parts.

- VAWTs have a higher airfoil pitch angle, giving improved aerodynamics while decreasing drag at low and high pressures.

- Straight bladed VAWT designs with a square or rectangular crossection have a larger swept area for a given diameter than the circular swept area of HAWTs.

- VAWTs have lower wind startup speeds than HAWTs. Typically, they start creating electricity at 6 m.p.h. (10 $\mathrm{km} / \mathrm{h})$.

- VAWTs usually have a lower tip speed ratio and so are less likely to break in high winds.

- VAWTs may be built at locations where taller structures are prohibited.

- VAWTs do not need to turn to face the wind if the wind direction changes.

- VAWT blades are easily seen and avoided by birds.

Disadvantages of Vertical Axis wind turbines (VAWT)[11,12]

- Most VAWTs produce energy at only $50 \%$ of the efficiency of HAWTs in large part because of the additional drag that they have as their blades rotate into the wind.

- VAWTs do not take advantage of the stronger wind at higher elevation.

- Most VAWTs have low starting torque, and may require energy to start the turning.

- $\quad$ A VAWT that uses guy wires to hold it in place puts stress on the bottom bearing as all the weight of the rotor is on the bearing. Guy wires attached to the top bearing increase downward thrust in wind gusts. Solving this problem requires a superstructure to hold a top bearing in place to eliminate the downward thrusts of gust events in guy wired models.

- While VAWTs' parts are located on the ground, they are also located under the weight of the structure above it, which can make changing out parts near impossible without dismantling the structure if not designed properly.

\section{GENERAL REQUIREMENT OF GRID INTERCONNECTION}

Thirty six states in US have adopted, and several Canadian provinces are considering adopting net metering programs, under which a utility customer can install a small on-site renewable power generator and sell electricity to the utility at the same rate at which he purchases it from the 
utility. Net metering programs have substantially improved the economy of small distributed resources (DR), including wind power. Although standards exist for large power plants connected to electric power systems, they fail to address special requirements for distributed resources. To provide guidelines for all stakeholders including utilities, independent power producers, users and equipment manufacturers, efforts are being made, both in Canada and internationally, to develop interconnection standards. Supported by Natural Resources Canada and Industry Canada, Electro-Federation Canada is developing Canadian guidelines for connecting small distributed resources to grids [8].

The guidelines will mainly address the interconnection issues of inverter based small power generators such as photovoltaic, wind, fuel cells and micro turbines. IEEE Standards Coordinating Committee 21 on Fuels, Photovoltaic, Dispersed Generation, and Energy Storage had formed working groups to develop IEEE P1547, the Draft Standard for Interconnecting Distributed Resources with Electric Power Systems, and P1589, the Draft Standard for Conformance Tests Procedures for Equipment Interconnecting Distributed Resources with Electric Power Systems (EPS).[9]. The major interconnection requirements for distributed resources can be summarized in the following three categories: general specifications, safety and protection, and power quality.

\section{A. General Requirements}

Voltage Regulation: A DR shall not cause the voltage at the Point of Common Coupling (PCC, see Figure 1) to go outside of Range A specified by Standard ANSI C84.1(or CSA CAN3-C235-83) [7]. For a 120/240V system, this specifies a maximum voltage of $126 / 252 \mathrm{~V}$ and a minimum voltage of 114/226V.[9]

Synchronization: When synchronizing, a DR shall not cause more than $+/-5 \%$ of voltage fluctuation at the PCC.

Monitoring: A DR of $250 \mathrm{~kW}$ or larger shall have provisions for monitoring connection status and real and reactive power output at the DR connection.

Isolation Device: A readily accessible, lockable, visiblebreak isolation device shall be located between the DR and the EPS.

\section{B. Safety and Protection Requirements}

Voltage Disturbances: At abnormal voltages, a DR shall cease to energize the EPS within the specified clearing time.

Frequency Disturbances: A DR shall cease to energize the EPS if the frequency is outside the range 59.3-60.5 Hz.

Loss of Synchronism: A DR of $250 \mathrm{~kW}$ or larger shall have loss of synchronism protection function.

Reconnection: A DR may reconnect to the power system $5 \mathrm{~min}$. after the EPS voltage and frequency return to normal.

Unintentional Islanding: A DR shall cease to energize the EPS within $2 \mathrm{sec}$. of the formation of an island.[10]

\section{Power Quality Requirements}

Harmonics: The total demand distortion of a DR, which is defined as the total rms harmonic current divided by the maximum demand load current, shall be less than 5\%. Each individual harmonic shall be less than the specified level.

DC Current Injection: A DR shall have a dc current injection of less than $0.5 \%$ of its rated output current.

Flicker: A DR shall not create objectionable flicker for other customers on the area EPS.

\section{Problems Related With GRID CONNECTIONS}

In Europe, substantial wind penetration exists today and will only increase over time. The impacts on the transmission network are viewed not as an obstacle to development, but rather as obstacles that must be overcome. High penetration of intermittent wind power (greater than 20 percent of generation meeting load) and may affect the network in the following ways and has to be studied in detail:

\section{A. Poor grid stability}

For economic exploitation of wind energy, a reliable grid is as important as availability of strong winds. The loss of generation for want of stable grid can be $10 \%$ to $20 \%$ and this deficiency may perhaps be the main reasons for low actual energy output of WEGs compared to the predicted output in known windy areas with adequate wind data.[22]

\section{B. Low-frequency operation}

Low frequency operation affects the output of WEGs in two ways. Many WEGs do not get cut-in, when the frequency is less than $48 \mathrm{~Hz}$ (for standard frequency of 50 $\mathrm{Hz}$ ) through wind conditions are favorable, with consequent loss in output [22].This deficiency apart, the output of WEGs at low frequency operation is considerably reduced, due to reduced speed of the rotor. The loss in output could be about 5 to $10 \%$ on the account of low frequency operation.

\section{Impact of low power factor}

WEGs fitted with induction generators need reactive power for magnetizing. Normally in conventional energy systems, generators apart from supplying active power will be supplying a reactive power. But in case of WEGs fitted with induction generators, instead of supplying reactive power to the grid, they absorb reactive power from grid, which undoubtedly is a strain on the grid. Suitable reactive power compensation [23] may be required to reduce the reactive power burden on the grid.

\section{Power flow}

It is to be ensured that the interconnecting transmission or distribution lines will not be over-loaded. This type of analysis is needed to ensure that the introduction of additional generation will not overload the lines and other electrical equipment. Both active and reactive power requirements should be investigated.

\section{E. Short circuit}

It is required to determine the impact of additional generation sources to the short circuit current ratings of existing electrical equipment on the network. 


\section{F. Power Quality}

Fluctuations in the wind power may have direct impact on the quality of power supply. As a result, large voltage fluctuations may result in voltage variations outside the regulation limits, as well as violations on flicker and other power quality standards.

\section{Autonomous Power Systems}

Hybrid power systems use local renewable resource to provide power. Village hybrid power systems can range in size from small household systems (100 Wh/day) to ones supplying a whole area (10's MWh/day). They combine many technologies to provide reliable power that is tailored to the local resources and community. Potential components include: PV, wind, micro-hydro, river-run hydro, biomass, batteries and conventional generators.[23] The different kinds of electrical power generators that might be used to feed power into a hybrid power system can be connected to the grid in several different ways shown in figure.4(a), (b), (c) below.[39]

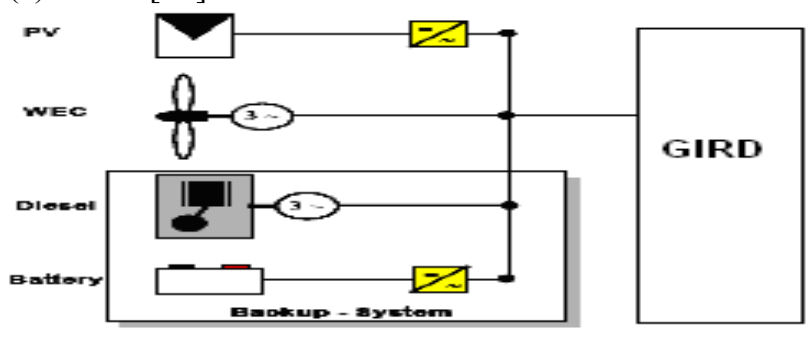

a) Centralized AC-bus model

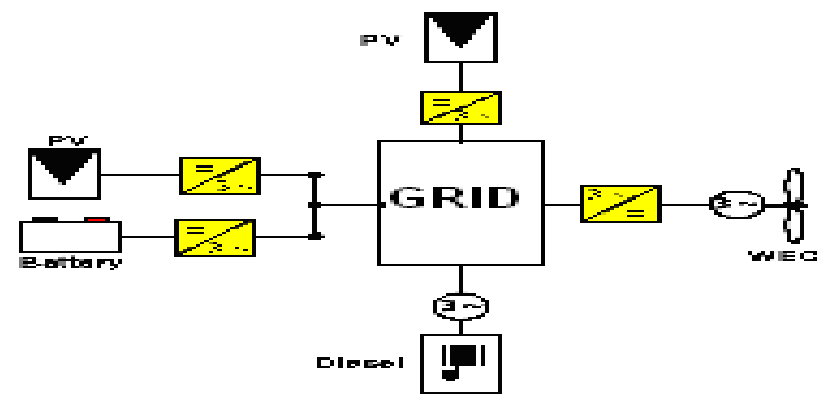

b) Distributed AC-bus model

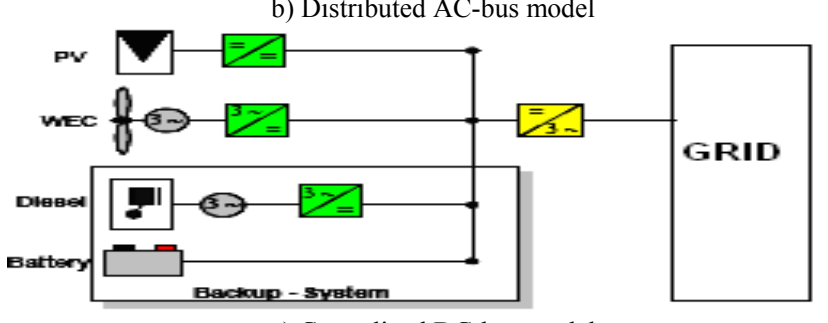

c) Centralized DC-bus model

Figure.4 Different Connection of Hybrid Power System with the grid

Energy storage devices, such as supercapacitors, flywheels, and also electrochemical batteries, are still under development. This means that in the near future their power densities and energy density capabilities are going to be improved. An estimation of the expected power/energy capabilities for these devices in the near future is shown in figure 5 .

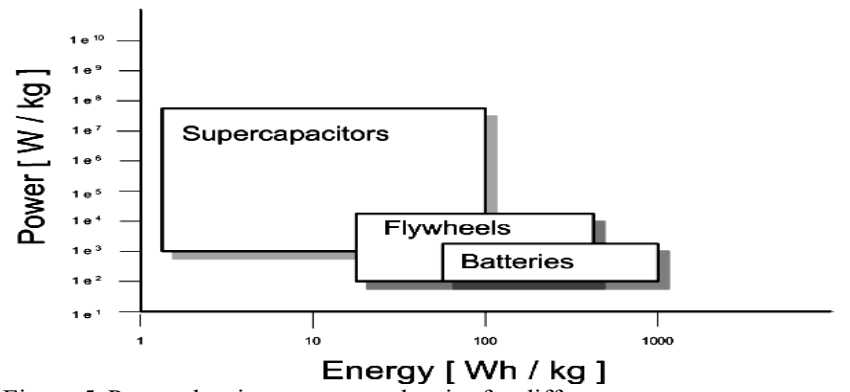

Figure.5 Power density vs. energy density for different energy storage devices

Generally, in an autonomous hybrid power system, the wind/hydro power generators are the main constituents of the system and are designed to operate in parallel with local diesel grids to improve the reliability of system. The main reasons are to obtain economic benefit of no fuel consumption by wind/hydro turbines, enhancement of power capacity to meet the increasing demand, to maintain the continuity of supply in the system, etc. As wind is highly fluctuating in nature and it will affect the quality of supply considerably and even may damage the system in the absence of proper control mechanism.

\section{ECONOMICS OF WIND POWER SYSTEMS}

The purpose of all types of energy generation ultimately depends on the economics. Renewable in general and wind in particular have seen generation costs falling over recent years. It is estimated that wind power in many countries is already competitive with fossil fuel and nuclear power if social/environmental costs are considered.[23] Installed cost of wind system is the cost of wind turbine, land, tower, and its accessories and it accounts less any state or federal tax credits. This tax credit may be base on how much wind energy is pumped into the grid or it may be percentage of installed cost. Maintenance cost of wind system is normally very small and annual maintenance cost may be about $2 \%$ of total system cost . The cost of financing to purchase the wind system can add significantly to overall cost of wind system. In addition there may be some hidden costs like property tax, insurance of wind system and any accident caused from the wind system, etc. On the other hand income from the wind system is the product of annual energy output and per unit cost of electricity. One of the chief advantages of generating electricity from wind system over conventional means is that fuel (wind) is free. The bulk of cost of wind system occurs once. On the other hand conventional generation consumes nonrenewable fuels whose cost continues to escalate. Research and development is going on to make wind power competitive with fossil fuel and nuclear power in strict sense, without taking into account of wind power's social factors such as environment benefits. Efforts are being made to reduce the cost of wind power by design improvement, better manufacturing technology, finding new sites for wind systems, development of better control strategies (for output and power quality control), development of policy and instruments, human resource development, etc.[23] 


\section{LATEST TREND OF WIND POWER GENERATION FROM} OFF SHORE SITES

In Europe, offshore projects are now springing up off the coasts of Denmark, Sweden, UK, France, Germany, Belgium, Irelands, Netherlands, and Scotland with approximate installed capacity of more than $250 \mathrm{MW}$. Recently, GE installed a wind turbine of largest capacity of 3.6 MW, having the rotor diameter of 104 meter for off shore sites. The next generation of off shore wind turbine will generally fall in the range of 3.5 to $5 \mathrm{MW}$. Largest off shore wind plant at Horns Rev of $160 \mathrm{MW}$ installed capacity consisting of 80 turbines each of $2 \mathrm{MW}$ capacity [33]. It is situated $54 \mathrm{~km}$ from the transmission network. Plant gets disconnected in case of grid faults, but it reconnects after few seconds the fault has disappeared. Some of the wind power plant's control functions are controlled centrally for the entire plant, where as others are managed by individual turbine. Reactive power can be controlled centrally or for each turbine, depending on the limits for intake and consumption. Each turbine has its own frequency control. In addition, the reactive power can be controlled locally so that wind power plant's total consumption/intake of reactive power is kept within \pm 16 MVAr at the $34 \mathrm{kV}$ side of wind farm transformer if the central control is not connected.

\section{CASE Study OF Wind Development In the Five LEADING COUNTRIES-}

The world's five leading countries in terms of installed wind power capacity are: Germany, Spain, United States, Denmark and India.

Germany: The installed wind power capacity was 48 MW in 1990. It increased to $12 \mathrm{GW}$ in 2002, the largest amount of installed capacity in the world. According to industry associations, installed capacity increased to 16.6 GW in 2004.7 Electricity productions from wind turbines was 18.5 TWh in 2003, more than $3 \%$ of Germany's electricity production. Industry sources estimate electricity production at 22.6 TWh in 2004. One-third of the world's installed wind power is in Germany. In 2002 there were about 16000 wind turbines, mostly situated in northern Germany near the border with Denmark. The impetus for the German wind power market was the $100 \mathrm{MW}$ Programme initiated in 1989 , which was expanded to 250 MW in 1991. This programme provided grants as well as remuneration under the Electricity Feed-in Law. The 1991 Feed-in Law is considered the driving force behind the rapid increase in wind power in Germany. It provided renewable energy producers up to $90 \%$ of the retail price of electricity for every $\mathrm{kWh}$ generated. The Renewable Energy Sources Act 2000 further strengthened market deployment by providing an incentive production payment for the first five years of operation followed by a decreasing output payment in subsequent years. Investment support provides up to $80 \%$ of total investment costs at low interest rates. Rapid deployment of wind power is also attributed to changes in codes that awarded wind farms the same legal rights as fossil and nuclear power plants. Wind turbines are largely connected to the grid at low and medium voltages. With the advent of the feed-in tariffs in 1991 and the spurt of wind developments that followed, the transmission system operators had concerns about grid integration reliability and cost issues. They looked to the government for a solution. The Renewable Energy Sources Act 2000 consequently provided for a burden sharing between all network operators and allocation to their customers. This solution is estimated to currently add about $€ 12$ per year to the average household electricity bill. The significant growth of onshore wind power led to collaboration between the transmission system operators and German research institutions to develop advanced forecasting and modeling tools for wind power. Subsequently, the expected extension offshore led to a more fundamental review of grid extension and upgrade needs, which culminated in a joint research effort between German research institutions, grid operators and the electricity supply industry. German researchers are also significantly involved in international and European research programmes on grid integration matters. The German Government has a target of $20 \%$ share of renewable energy in electricity generation between 2015 and 2020. Most of this is expected to come from wind power. Concerns about network integration and infrastructure capacity to accommodate some $37 \mathrm{GW}$ of wind power by 2015 were the impetus for a federal government and industry joint-financed report released in February 2005, "Energy Planning for the Integration of Wind Energy in Germany on Land and Offshore into the Electricity Grid".8 It finds that reinforcement and extension of the grid and technical solutions for reliability are preconditions for achieving the envisaged wind power development and avoiding 20 to 40 million tons of $\mathrm{CO} 2$ emissions in 2015. It would entail about 850 kilometers of new high-voltage lines and $400 \mathrm{~km}$ of grid upgrades at an estimated cost of $€ 1.1$ billion. The study cautions that implementation could be stymied by the planning and legal authorization process for transmission lines. The study suggests that the additional cost for the expansion of wind power will be $0.39-0.49 €$ cents per $\mathrm{kWh}$ in 2015 for a residential consumer.

Spain: The installed wind power capacity was $2 \mathrm{MW}$ in 1990. It increased to $4.8 \mathrm{GW}$ in 2002, the second largest in the world. According to industry associations, installed capacity increased to $8.2 \mathrm{GW}$ in 2004. Electricity production from wind turbines was 11.5 TWh in 2003. Industry sources estimate electricity production at $14 \mathrm{TWh}$ in 2004, about $4 \%$ of Spain's electricity production. Strong growth is attributed to local manufacturing of turbines and policy support through feed-in tariffs and low-interest loans. An important impetus has come from regional governments that support the construction of factories and the creation of local jobs. Three Spanish companies are among the world's ten largest manufacturers of wind turbines. Favorable lending arrangements, in which banks guarantee the cash flow of the project thereby reducing risks, have been very effective in increasing wind power. The incentive structures have favored large wind developments that are connected to the high voltage transmission network. Weak grid infrastructure in some areas has inhibited the development of wind farms. This led to a comprehensive review of 
transmission and distribution requirements by the grid operator, which is concerned about system impacts from more large-scale wind farms and the costs of integration. At present, Spain's transmission system interconnections with neighboring countries are weak so opportunities afforded through power pools are limited.

United States: The installed wind power capacity was 1 $911 \mathrm{MW}$ in 1990. It increased to $4.4 \mathrm{GW}$ in 2002, the third largest in the world. According to industry associations, installed capacity increased to $6.7 \mathrm{GW}$ in 2004 . Electricity production from wind turbines was 11.5 TWh in 2003. Wind power experienced two distinct periods of growth in the United States. The Public Utility Regulatory Act (PURPA) in 1978 required utilities to offer long-term power purchase contracts to private power developers that were based on the utilities' avoided generation costs. There were also federal and state tax incentives. Most of the early development occurred in California where utilities had high marginal costs. In the late 1990s there was a second period of growth spurred by a combination of federal tax incentives and policies adopted in several states, e.g., renewable portfolio standards. The new generation of wind turbine technology available by then further supported the interest of utilities. In Texas nearly $1000 \mathrm{MW}$ of wind power development were installed in 2001, in part to meet the state's renewable energy portfolio standard. Voluntary green power marketing programmes have also encouraged wind power developments, which represent a significant share of the green power sold in the United States. One of the federal incentives, the production tax credit (PTC) dating back to 1992, has been allowed to expire several times. Its on-again - off-again nature has resulted in boomand-bust cycles for new installed capacity. The PTC was revived late in 2004 and set to expire at the end of 2005, which therefore is expected to be a record year for newly installed capacity. To date, intermittency, per se, has not been an obstacle to wind projects in the United States. Wind power developments have been largely in remote areas and connected to high voltage transmission networks. However, access to transmission networks and pricing for intermittent resources has been a hurdle. In 2004, the Federal Energy Regulatory Commission proposed modifications in the wholesale electricity market structure that would eliminate penalties associated with wind's variable output when it does not result in increased costs to the system. This proposal is currently under consideration. With significant growth anticipated, the wind energy and electric power industries, research institutions and the federal government are working collaboratively to address issues related to the integration of larger amounts of wind power, including cojoining wind farms with hydropower plants. As an example of this type of innovation and integrated resource management, in 2002 the Bonneville Power Administration (BPA) undertook an extensive R\&D effort to evaluate the costs and opportunities associated with integrating wind energy into the federal Columbia River hydropower system. In May 2004, BPA launched two new services that will use the flexibility of the hydro system to integrate wind energy into its control area on behalf of electric utilities in the US Pacific Northwest region.
Denmark: The installed wind power capacity was 343 MW in 1990. It increased to $2.9 \mathrm{GW}$ in 2002 , the fourth largest in the world. Wind turbine capacity represented $21.8 \%$ of Denmark's electricity supply in 2002. According to industry associations, installed capacity increased to 3.1 GW in 2004, but only $2 \mathrm{MW}$ were added that year. Offshore capacity was $214 \mathrm{MW}$ in 2002, up from $50 \mathrm{MW}$ in 2001. Electricity production from wind turbines was 5.5 TWh in 2003, about $16 \%$ of Denmark's electricity production. Industry sources estimate electricity production at 6.6 TWh in 2004 , about $19 \%$ of electricity production. In Denmark, each MW of capacity produces an average of $2129 \mathrm{MWh}$ a year - much more than the world average. Denmark has successfully and flexibly employed both demand pull and technology push policy instruments to achieve its wind power targets. For example, the Risø National Laboratory established a test station in 1978 for wind turbines that was responsible for type approvals that were a precondition for obtaining plant and production subsidies. Ris $\varnothing$ functioned as a technological service centre for the nascent Danish wind turbine industry, whose individual companies at that point did not have the resources to undertake technological development. Government RD\&D has been directed towards basic research rather than actual turbine or component development and had enjoyed a relatively stable level of support. The technological developments led to significant growth in demand for wind turbines in the 1990s in both domestic and export markets. Within Denmark, the technological advances were coupled with market deployment strategies building on a policy combination of feed-in tariffs and subsidies for installation costs. Utilities were required to connect private wind turbines to the grid. An agreement was established between utilities, government and wind turbine owners in the early wind power development period. Among other features, it established the grid connection rules, and particularly who should pay. Grid integration costs are paid by the network and allocated to all customers. The Danish Government supported wind to help achieve energy goals and other policy objectives, e.g., industrial development and rural employment. Investments were made in RD\&D and learning in a niche market to improve technology cost and performance. Through the development years, the Danish state financed the additional costs involved. Following liberalization of the electricity market and reflecting the maturing of the wind power technology, the economic commitment shifted to consumers. The support scheme is being reorganized and following a transition period, wind turbines will have to produce on market terms, but with a bonus that capitalizes on the environmental and societal benefits of wind power. Denmark has the highest penetration of wind power in its electricity supply systems of any country. About $93 \%$ of the wind generation is fed into the distribution networks. Wind farms in Denmark are generally small clusters in the 10-20 MW range and are widely dispersed across the country, which means lower volatility of output in the short-term and therefore less need for balancing power. With this profile, the variations in output are less than for very large and isolated wind farms and therefore more manageable for network operators. In addition, wind power in combination 
with combined heat and power generation, which is widespread in Denmark, provides some of the needed power regulation flexibility as the district heating systems can be used as a short-term energy buffer. As well, the Danish transmission system has strong interconnections with Germany and the Nordic countries and participation in the Nordpool power market is an important means for selling excess capacity and purchasing additional balancing power as and when needed. Danish network operators, utilities, government and research institutions are active in international and European collaborative research on grid integration matters.

India: According to the India Wind Association, the installed wind power capacity was $30 \mathrm{MW}$ in 1990. It increased to $2117 \mathrm{MW}$ in 2002, the fifth largest in the world. Installed capacity increased to $3000 \mathrm{MW}$ in 2004. The first wind power development was a government supported demonstration plant in 1986. India had notable wind power developments by the late $1990 \mathrm{~s}$, largely due to incentives such an accelerated depreciation allowance of capital costs and exemptions from excise duties and sales taxes, and regionally administered feed-in tariffs. A tax rebate of $80 \%$ on the income from power generation for the first ten years of operation has encouraged commercial investment, as has the attraction of power supply for use in businesses. Since the first demonstration plant, some 2052 MW of installed wind capacity has been developed by commercial interests. In some cases they are not well integrated as the wind turbines produce more power that the weak distribution system can handle. The government Centre of Wind Energy Technology (C-WET) in Chennai is a specialized institution for research and development, standardization, testing and certification, along with resource assessment. Risø National Laboratory provided technical assistance for its establishment. With rapid growth in wind power development in the 1990s, the capacity of the grids in the wind farm regions in TamilNadu and Gujarat was insufficient to accommodate the wind power. It caused frequent outages of the grid and reduced the return from the wind farms. In 1998, Ris $\varnothing$ and C-WET collaborated on a research project to study wind power integration in weak grids in India. India has developed indigenous wind energy equipment manufacturing with a capacity of about 1000 MW per year.

\section{UTILIZATION OF WIND POWER}

TABLE-1

\begin{tabular}{|r|c|r|r|r|}
\hline \multicolumn{5}{|c|}{ Installed windpower capacity $(\mathrm{MW})^{[25,26,27]}$} \\
\hline $\begin{array}{r}\mathrm{Ra} \\
\text { nk }\end{array}$ & Nation & 2005 & 2006 & 2007 \\
\hline 1 & Germany & 18,415 & 20,622 & 22,247 \\
\hline 2 & United States & 9,149 & 11,603 & 16,818 \\
\hline 3 & Spain & 10,028 & 11,615 & 15,145 \\
\hline 4 & India & 4,430 & 6,270 & 8,000 \\
\hline 5 & China & 1,260 & 2,604 & 6,050 \\
\hline 6 & Denmark (\& Faeroe & 3,136 & 3,140 & 3,129 \\
\hline
\end{tabular}

\begin{tabular}{|c|c|c|c|c|}
\hline & Islands) & & & \\
\hline 7 & Italy & 1,718 & 2,123 & 2,726 \\
\hline 8 & France & 757 & 1,567 & 2,454 \\
\hline 9 & United Kingdom & 1,332 & 1,963 & 2,389 \\
\hline 10 & Portugal & 1,022 & 1,716 & 2,150 \\
\hline 11 & Canada & 683 & 1,459 & 1,856 \\
\hline 12 & Netherlands & 1,219 & 1,560 & 1,747 \\
\hline 13 & Japan & 1,061 & 1,394 & 1,538 \\
\hline 14 & Austria & 819 & 965 & 982 \\
\hline 15 & Greece & 573 & 746 & 871 \\
\hline 16 & Australia & 708 & 817 & 824 \\
\hline 17 & Ireland & 496 & 745 & 805 \\
\hline 18 & Sweden & 510 & 572 & 788 \\
\hline 19 & Norway & 267 & 314 & 333 \\
\hline 20 & New Zealand & 169 & 171 & 322 \\
\hline 21 & Egypt & 145 & 230 & 310 \\
\hline 22 & Belgium & 167 & 193 & 287 \\
\hline 23 & Taiwan & 104 & 188 & 282 \\
\hline 24 & Poland & 83 & 153 & 276 \\
\hline 25 & Brazil & 29 & 237 & 247 \\
\hline 26 & South Korea & 98 & 173 & 191 \\
\hline 27 & Turkey & 20 & 51 & 146 \\
\hline 28 & Czech Republic & 28 & 50 & 116 \\
\hline 29 & Morocco & 64 & 124 & 114 \\
\hline 30 & Finland & 82 & 86 & 110 \\
\hline 31 & Ukraine & 77 & 86 & 89 \\
\hline 32 & Mexico & 3 & 88 & 87 \\
\hline 33 & Costa Rica & 71 & 74 & 74 \\
\hline 34 & Bulgaria & 6 & 36 & 70 \\
\hline 35 & Iran & 23 & 48 & 66 \\
\hline \multirow[t]{7}{*}{36} & Hungary & 18 & 61 & 65 \\
\hline & Rest of Europe & 129 & 163 & \\
\hline & Rest of Americas & 109 & 109 & \\
\hline & Rest of Asia & 38 & 38 & \\
\hline & $\begin{array}{l}\text { Rest of Africa \& } \\
\text { Middle East }\end{array}$ & 31 & 31 & \\
\hline & Rest of Oceania & 12 & 12 & \\
\hline & World total (MW) & 59,091 & 74,223 & 93,849 \\
\hline
\end{tabular}

TABLE-2 


\begin{tabular}{|c|c|c|c|c|}
\hline \multirow{2}{*}{ Rank } & \multirow{2}{*}{ Matian } & \multicolumn{3}{|c|}{2005} \\
\hline & & Wind Power & $\%$ & Total Power \\
\hline 1 & Germany & 27.225 & 5.1 & 533.700 \\
\hline 2 & $\begin{array}{l}\text { United } \\
\text { States }\end{array}$ & & & 4049.8 \\
\hline 3 & Spain & 23.166 & 9.1 & 25490 \\
\hline 4 & India & & & 6792 \\
\hline$s$ & China & & & 2474.7 \\
\hline 6 & $\begin{array}{c}\text { Dermmark (\& } \\
\text { Faeroe } \\
\text { Ishnds) }\end{array}$ & 6.614 & 193 & 34.30 \\
\hline 7 & FHance & & & 5478 \\
\hline 8 & United & 0.973 & 0.2 & 407365 \\
\hline 9 & Portugal & & & 35.0 \\
\hline & $\begin{array}{c}\text { Wald } \\
\text { total (Twhis) }\end{array}$ & & & $15746.54^{\mid 32]}$ \\
\hline
\end{tabular}

TABLE-3

\begin{tabular}{|c|c|c|c|c|}
\hline & & & & \\
\hline \multirow{2}{*}{ Rank } & \multirow{2}{*}{ Hatian } & \multicolumn{3}{|c|}{2006} \\
\hline & & Wind Power & $\%$ & Total Fowrer \\
\hline 1 & Genmary & 30.700 & 5.4 & 569.943 \\
\hline 2 & $\begin{array}{l}\text { United } \\
\text { States }\end{array}$ & $263^{|47|}$ & 0.6 & 4104.967 \\
\hline 3 & Spain & 29.777 & 10.1 & 294.596 \\
\hline 4 & India & & & 726.7 \\
\hline 5 & Chins & 2.70 & 0.1 & 2834.4 \\
\hline 6 & $\begin{array}{l}\text { Dermanith (\& } \\
\text { Faeroe } \\
\text { Ishris) }\end{array}$ & 7.432 & 168 & 44.24 \\
\hline 7 & France & 2323 & 0.4 & 550.063 \\
\hline 8 & United & & & 383.898 \\
\hline 9 & Portugal & 4.74 & 9.7 & 48.876 \\
\hline & $\begin{array}{c}\text { Wald } \\
\text { tutsl (TWMM) }\end{array}$ & & & $167900^{\mid 33]}$ \\
\hline
\end{tabular}

TABLE-4

\begin{tabular}{|c|c|c|c|c|}
\hline \multirow{2}{*}{ Rank } & \multirow{2}{*}{ Natian } & \multicolumn{3}{|c|}{2007} \\
\hline & & wind & $\%$ & Total Powrer \\
\hline 1 & Gremang & 39.500 & 68 & $584.939^{\mid 61}$ \\
\hline 2 & $\begin{array}{l}\text { United } \\
\text { States }\end{array}$ & & & 4179.908 \\
\hline 3 & Spain & & & 303.758 \\
\hline 4 & Fudia & $14 \pi$ & 19 & 774.7 \\
\hline 5 & Crina & & & 3255.9 \\
\hline$\sigma$ & $\begin{array}{c}\text { Dermanik (\&) } \\
\text { Faeroe } \\
\text { Ishruds) }\end{array}$ & & & 37.276 \\
\hline 7 & France & & & 545289 \\
\hline 8 & Urited & & & 379.756 \\
\hline 9 & Portugal & & & \\
\hline & $\begin{array}{c}\text { Mald } \\
\text { total (TwM) }\end{array}$ & & & \\
\hline
\end{tabular}

Table 2,3,4 above shows Annual Wind Power Generation (TWh) / Total electricity consumption(TWh)[28,29,30,31] for the year 2005,2006\&2007 respectively.

The modern wind power industry began in 1979 with the serial production of wind turbines by Danish manufacturers Kuriant, Vestas, Nordtank, and Bonus. These early turbines were small by today's standards, with capacities of 20 to 30 $\mathrm{kW}$ each. Since then, they have increased greatly in size, while wind turbine production has expanded to many countries all over the world.

There are now many thousands of wind turbines operating, with a total capacity of $73,904 \mathrm{MW}$ of which wind power in Europe accounts for 65\% (2006). Wind power was the fastest growing energy source at the end of 2004. World wind generation capacity more than quadrupled between 2000 and 2006. 81\% of wind power installations are in the US and Europe, but the share of the top five countries in terms of new installations fell from $71 \%$ in 2004 to $62 \%$ in 2006 .

In 2007, the countries with the highest total installed capacity were Germany, the United States, Spain, India, and China (see chart).

By 2010, the World Wind Energy Association expects $160 \mathrm{GW}$ of capacity to be installed worldwide, ${ }^{[50]}$ up from $73.9 \mathrm{GW}$ at the end of 2006, implying an anticipated net growth rate of more than $21 \%$ per year.

\section{ENVIRONMENTAL EFFECTS OF Wind POWER}

Compared to the environmental effects of traditional energy sources, the environmental effects of wind power are relatively minor. Wind power consumes no fuel, and emits no air pollution, as do fossil fuel power sources. The energy consumed to manufacture and transport the materials used to build a wind power plant is equal to the new energy produced by the plant within a few months of operation. Garrett Gross, a scientist from UMKC in Kansas City, Missouri states, "The impact made on the enviroment is very little when compared to what is gained." The initial carbon dioxide emission from energy used in the installation is "paid back" within about 9 months of operation for off shore turbines.

Danger to birds and bats is often the main complaint against the installation of a wind turbine. However, studies show that the number of birds killed by wind turbines is negligible compared to the number that die as a result of other human activities, and especially the environmental impacts of using non-clean power sources. Bat species appear to be at risk during key movement periods. Almost nothing is known about current populations of these species and the impact on bat numbers as a result of mortality at wind power locations. Offshore wind sites $10 \mathrm{~km}$ or more from shore do not interact with bat populations. While a wind farm may cover a large area of land, many land uses such as agriculture are compatible, with only small areas of turbine foundations and infrastructure made unavailable for use.

Aesthetics have also been a concern. The Massachusetts Cape Wind project was delayed for years mainly because of aesthetic concerns. Wind power consumes no fuel for continuing operation, and has no emissions directly related to electricity production. Operation does not produce carbon dioxide, sulfur dioxide, mercury, particulates, or any other type of air pollution, as do fossil fuel power sources. Wind power plants consume resources in manufacturing and construction. During manufacture of the wind turbine, steel, concrete, aluminum and other materials will have to be made and transported using energy-intensive processes, 
generally using fossil energy sources. The initial carbon dioxide emissions "pay back" is within about 9 months of operation for off shore turbines.[34]

Unlike fossil fuel and nuclear power stations, which circulate or evaporate large amounts of water for cooling, wind turbines do not need water to generate electricity. However, leaking lubricating oil or hydraulic fluid running down turbine blades may be scattered over the surrounding area, in some cases contaminating drinking water areas. Clearing of wooded areas is often unnecessary. Farmers commonly lease land to companies building wind farms. In the U.S., farmers may receive annual lease payments of two thousand to five thousand dollars per turbine. The land can still be used for farming and cattle grazing[35]

As the number of offshore wind farms increase and move further into deeper water, the question arises if the ocean noise that is generated due to mechanical motion of the turbines and other vibrations which can be transmitted via the tower structure to the sea, will become significant enough to harm sea mammals. Tests carried out in Denmark for shallow installations showed the levels were only significant up to a few hundred metres. However, sound injected into deeper water will travel much further and will be more likely to impact bigger creatures like whales which tend to use lower frequencies than porpoises and seals. A recent study found that wind farms add $80-110 \mathrm{~dB}$ to the existing low-frequency ambient noise (under $400 \mathrm{~Hz}$ ), which could impact baleen whales communication and stress levels, and possibly prey distribution [36] While some tourism officials predict wind farms will damage tourism, some wind farms have themselves become tourist attractions. [37].

Impact on wildlife- Danger to birds is often the main complaint against the installation of a wind turbine. However, studies show that the number of birds killed by wind turbines is negligible compared to the number that die as a result of other human activities such as traffic, hunting, power lines and high-rise buildings, the [38]introduction of feral and roaming domestic cats and especially the environmental impacts of using non-clean power sources. For example, in the UK, where there are several hundred turbines, about one bird is killed per turbine per year; 10 million per year are killed by cars alone. In the United States, turbines kill 70,000 birds per year, compared to 57 million killed by cars, 97.5 million killed by collisions with plate glass, and hundreds of millions killed by cats. An article in Nature stated that each wind turbine kills on average 0.03 birds per year, or one kill per thirty turbines.

\section{CONCLUSIONS}

An attempt has been made in this paper to discusses number of issues related to the power generation from WECs, i.e. factors affecting wind power, their classification, choice of generators, main design considerations in wind turbine design, problems related with grid connections, wind-diesel autonomous hybrid power systems, reactive power control of wind system, environmental aspects of power generation, latest trend of wind power generation from off shore sites. Today wind power accounts for about
$0.4 \%$ of world's electricity demand. And there is a target estimated by EWEA to reach wind power generation nearly $12 \%$ of the world's electricity supply by 2020 , which needs strong political commitment worldwide wind energy industry could install an estimated 1200, 000 MW by 2020, which needs global exploitation of available wind potential and to generate power from off shore sites.

\section{REFERENCES}

[1] Gipe, P. (1995) 'Wind power', Chelsea Green Publishing Company, Post Mills, Vermount, USA.

[2] Rai, G.D. (2000) 'Non conventional energy sources', Khanna Publishers, 4th Edition, New Delhi (India)

[3] Hunter, R., and Elliot, G. (1994) 'Wind-diesel systems, a guide to the technology and its implementation', Cambridge University Press, Great Britain.

[4] Wind Power: Capacity Factor, Intermittency, and what happens when the wind doesn't blow? Retrieved 24 January 2008.

[5] Wind Power in Ontario these wind farms have capacity factors of about 28 to $35 \%$. International Energy Agency, Wind Annual report 2000, May 2001.

[6] The power of multiples: Connecting wind farms can make a more reliable and cheaper power source" (2007-11-21).

[7] R. Mittal, K.S. Sandhu and D.K. Jain ,"Sustainable Growth Through Wind Energy for Distributed Generation", Proceddings of National conference on Current Trends in Electrical Engineering-08, Bhatinda, 2008,pp-35-38.

[8] Archer, C. L.; Jacobson, M. Z. (2007), "Supplying Baseload Power and Reducing Transmission Requirements by Interconnecting Wind Farms", Journal of Applied Meteorology and Climatology (American MeteorologicalSociety)46(11):1701-1717,

[9] Vries, E.D. (2002) 'On a grand scale: the world's largest commercial wind prototype'Renewable Energy World, Vol. 5, No. 5, pp. 70-75.

[10] National Electrical Manufactureers Association,ANSI C 84.11995,Electrical Power System and Equipment-VoltagRegulation, 1995

[11] Draft Standard for Interconnecting Distributed Resources with Electric Power Systems, IEEE std. P1547/07.

[12] Ahmad Y Hassan, Donald Routledge Hill (1986). Islamic Technology: An illustrated history, p. 54. Cambridge University Press. ISBN 0521-42239-6.

[13] Donald Routledge Hill, "Mechanical Engineering in the Medieval Near East", Scientific American, May 1991, p. 64-69. (cf. Donald Routledge Hill, Mechanical Engineering

[14] Bansal, R.C., Bhatti, T.S., and Kothari, D.P. (2002) 'On some of the design aspects of wind energy conversion systems", Int. Journal of Energy Conversion and Management, Nov. Vol. 43, No. 16, pp. 21752187.

[15] Johnson, G.L. (1978) 'Economic design of wind electric generators', IEEE Transactions on Power Apparatus and Systems, March/April, Vol. PAS-97, No. 2, pp. 554-562.

[16] Jayadev, T.S. (1976) 'Windmills stage a comeback, Nov., IEEE Spectrum, pp. 45-49..International Journal of Emerging Electric Power Systems Vol. 3 [2005], No. 2, Article 1070

[17] Muller, S., Deicke, M., and Doncker, R.W.D. (2002) 'Doubly fed induction generator systems, IEEE Industry Applications Magzine, May/June, pp. 26- 33.

[18] Singh, B. (1995) 'Induction generator-a prospective', Electric Machines and Power Systems, Vol. 23, pp. 163-177.

[19] Rajveer Mittal, K.S.Sandhu, D.K.Jain ,"Controlled Operation of Variable Speed Driven PMSG for Wind Energy Conversion System", published in WSEAS Transactions on Systems, issue 2, vol.8, 2009, pp-189-199.

[20] Rajveer Mittal, K.S.Sandhu, D.K.Jain ,'Ride-through Capability of Grid Interfaced Variable Speed Driven PMSG for Wind Energy Conversion System", published in an International conference on Energy \& Envirionment, March-19-21, 2009 held at Chandigarh(ENVIROENERGY-2009) pp-406-412

[21] Bansal, R.C., Bhatti, T.S., and Kothari, D.P. (2001) 'Some aspects of grid connected wind electric energy conversion system,Interdisciplinary Journal of Institution on Engineers (India), May, Vol. 82, pp. 25-28.

[22] Saad-Saund, Z., Lisboa, M.L., Ekanayka, J.B., Jenkins, N. and Strbac, G. (1998) 'Application of Statcoms to Wind farms', IEE proceedings- 
Generation, Transmission and Distribution, Sept. Vol. 145, No. 5, pp. 511-516.

[23] Beurskens, J. and Jensen, P.H. (2001) 'Economics of wind energyprospects and directions, Renewable Energy World, Vol. 4, No. 4, pp. 103-121.

[24] Bonefeld, J. and Jensen, J.N. (2002) 'Horns Rev- $160 \mathrm{MW}$ offshore wind', Renewable Energy World, Vol. 5, No. 3, pp. 77-87.

[25] "Global Wind Energy Council (GWEC) statistics" (PDF).

[26] "European Wind Energy Association (EWEA) statistics" (PDF)

[27] Global installed wind power capacity (MW) Global Wind Energy Council 6.2.2008

[28] http://www.sp.com.cn/sjdl/sjdltj/sjdltj0612.htm

[29] http://www.sp.com.cn/sjdl/sjdltj/sjdltj0512.htm

[30] Energy Information Administration - International Electricity Generation Data

[31] International Electricity Consumption

[32] The World Factbook - Rank Order - Electricity - consumption

[33] Vestas: Life Cycle Assessments (LCA)". Retrieved on 2008-02-13.

[34] RENEWABLE ENERGY - Wind Power's Contribution to Electric Power Generation and Impact on Farms and Rural Communities (GAO-04-756). United States Government Accountability Office (September 2004). Retrieved on 2006-04-21.

[35] "Ocean Noise: What We Learned in 2006"'. Acoustic Ecology Institute. Retrieved on 2008-01-15

[36] "Tourism blow for windfarm". Sunday Mirror (2003-05-30). Retrieved on 2008-09-06.

[37] C V Nayar, "Stand Alone Wind/Diesel/Battery Hybrid Energy Systems", Wind Engineering Journal, Vol.21, No.1, pp 13-19, 1997

[38] "Cats Indoors! The American Bird Conservancy's Campaign for Safer Birds and Cats". National Audubon Society. Retrieved on 2008-08-25.

\section{BIOGRAPHIES}

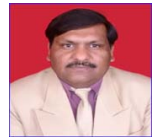

Rajveer Mittal received his B.E degree in Electrical Engineering from R.E.C, Kurukshetra ,Haryana, India in 1987, the M.E degree in Electrical Engineering (Instrumentation \& Control) from Delhi College of Engineering, Delhi University, Delhi, India in 2003, and is currently pursuing the Ph.D. degree in the research area of "Power Quality Studies of Wind Energy Systems" of Electrical Engineering from N.I.T, Kurukshetra , Haryana, India. Currently, he is working as a Asst.Prof. in EEE Department with the Maharaja Agrasen Institute of Technology, Rohini, Delhi under GGSIP University, Delhi, India. His research interests include power quality, motor drives, and Renewable energy.

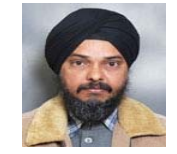

Dr.K.S.Sandhu received the B.Sc. Engg. (Electrical), M. Sc. (Electrical) and $\mathrm{PhD}$ (Electrical Machines) degrees from Regional Engineering College, Kurukshetra University, India in 1981, 1985 and 2001, respectively. He joined the Electrical Engineering Department of Regional Engineering College, Kurukshetra, as Lecturer in January 1983. Currently, he is Professor in Electrical Engineering Department, National Institute of Technology, Kurukshetra India His areas of interest include electrical machines, wind energy conversion, power quality, power systems and artificial intelligence

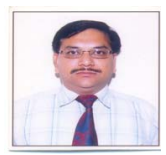

Dr.D.K.Jain received his B.Tech, M.Tech and Ph.D. degree in Electrical Engineering from R.E.C, Kurukshetra, India. Currently, he is working as Director Guru Prem Sukh Memorial College of engineering under GGSIP University, Delhi, India. His research interests include electric power quality, motor drives, and renewable energy systems. 